\title{
Dr. R. Tait McKenzie: pioneer and legacy to physiatry.
}

John F. Ditunno, Jr

Thomas Jefferson University

Richard E. Verville

Powers Pyles Sutter \& Verville PC

Follow this and additional works at: https://jdc.jefferson.edu/rmfp

Part of the Rehabilitation and Therapy Commons

Let us know how access to this document benefits you

\section{Recommended Citation}

Ditunno, Jr, John F. and Verville, Richard E., "Dr. R. Tait McKenzie: pioneer and legacy to

physiatry." (2014). Department of Rehabilitation Medicine Faculty Papers. Paper 49.

https://jdc.jefferson.edu/rmfp/49

This Article is brought to you for free and open access by the Jefferson Digital Commons. The Jefferson Digital Commons is a service of Thomas Jefferson University's Center for Teaching and Learning (CTL). The Commons is a showcase for Jefferson books and journals, peer-reviewed scholarly publications, unique historical collections from the University archives, and teaching tools. The Jefferson Digital Commons allows researchers and interested readers anywhere in the world to learn about and keep up to date with Jefferson scholarship. This article has been accepted for inclusion in Department of Rehabilitation Medicine Faculty Papers by an authorized administrator of the Jefferson Digital Commons. For more information, please contact: JeffersonDigitalCommons@jefferson.edu. 
Title: R. Tait McKenzie: Pioneer and Legacy to Physiatry

Authors: John F. Ditunno, Jr., M.D. ${ }^{1}$ and Richard E. Verville, JD ${ }^{2}$

${ }^{1}$ Regional Spinal Cord Injury Center of the Delaware Valley, Department of Rehabilitation Medicine, Thomas Jefferson University, Philadelphia, PA 19107;

${ }^{2}$ Powers Pyles Sutter \& Verville PC, Washington, DC

\section{Corresponding Author}

John F. Ditunno, Jr., M.D.

Regional Spinal Cord Injury Center of the Delaware Valley

Thomas Jefferson University

132 South 10th Street, 375 Main Building

Philadelphia, PA 19107

Phone: 215-955-6579

e-mail: John.Ditunno@jefferson.edu

fax: 215-955-5152

Disclosure: nothing to disclose 
*3.) Blinded Manuscript (without personal identifiers)

1

2

3

4

5

7

8

9

10

11

12

13

14

15

16

17

18

19

20

21

22

23

5

7

9

10

1

5

6

7

Manuscript (without personal identifiers)

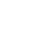

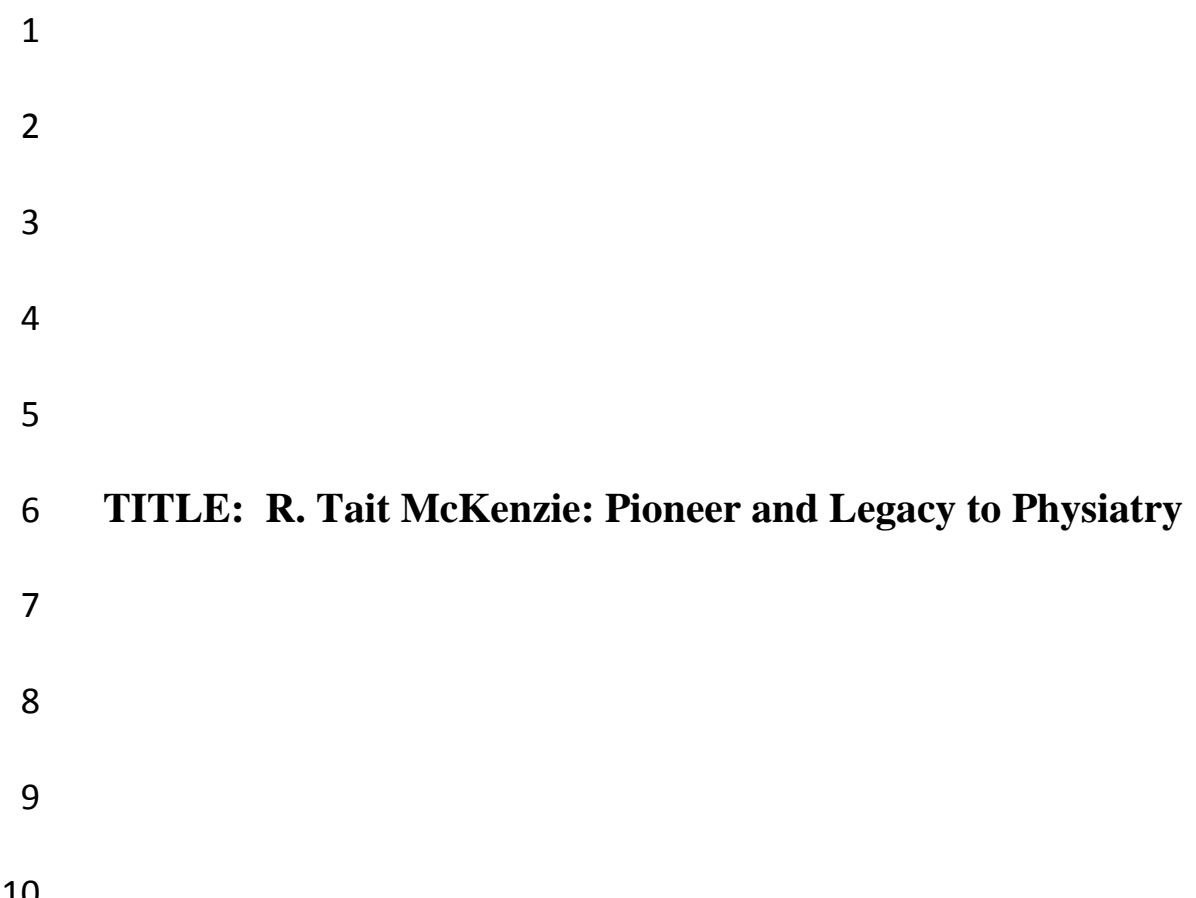

.

8

.

(

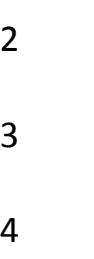

2

3

4

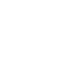

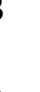

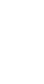

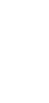

1

2

3


"In history, a great volume is unrolled for our instruction, drawing the materials of future wisdom from the past errors and infirmities of mankind."

\section{Edmund Burke}

INTRODUCTION contributions to the scientific development of physical training and therapeutic exercise in restoring function and reducing disability. McKenzie's legacy to PM\&R is his fundamental concept, much later articulated by the American College of Sports Medicine, as to the importance of frequency, intensity, time, type, volume, and progression of therapeutic exercise [1,2]. His classic book [3] instructs physicians for the first time as to the scientific value of exercise in health and disease. He categorizes the specific pathological conditions that can be effectively treated with exercise, and he emphasizes the precision necessary in dosage and timing to achieve the benefit. In the preface to his first book, Exercise in Education and Medicine [3], he exposes the medical profession's one-dimensional approach to therapeutics, i.e. an emphasis only on pharmacology, an approach that has prevailed until very recent times [4].

"Perhaps a certain laziness which is inherent in both patient and physician tempts to the administration of a pill or draught to purge the system of what should be used in normal muscular activity, but there is a wide dearth of knowledge among the [ medical] profession of the scope and application of exercise in pathologic conditions, and the necessity of care in the choice and accuracy of the dosage will be 46 
47 As a scientist and clinician, McKenzie also recognized the lack of interest by the medical

48 profession in the physiology of exercise and the importance of physical training for promoting

49 good health and function.

50 McKenzie's use of physical therapy in the rehabilitation of the war wounded in Great

51 Britain, Canada, and the United States during World War I (WW I) entitles him to recognition as

52 one of the earliest pioneers of physical medicine and rehabilitation (PM\&R). His second

53 textbook, Reclaiming the Maimed: A Handbook of Physical Therapy [5], was used by the

54 military in all three countries to develop and establish physical therapy services in the

55 Reconstruction Hospitals during WW I. His work influenced physiatrists Frank Granger, George

56 Deaver [6] and John Stanley Coulter, three major leaders in the field in the decades following the

57 war.

58

\section{EARLY INFLUENCES: MCGILL, HARVARD, AND SPRINGFIELD}

McKenzie experienced a "fascination [with] acrobatics and gymnastics" during his early undergraduate years at McGill University [7]. He competed in track and field and set the intercollegiate high jump record in 1886 before entering medical school. During his medical school days, he developed his first interests in physical education and was inspired by Dudley A. Sargent, MD, who conducted a six-week course at the Harvard Summer School [8]. McKenzie attended courses for two summers in 1889-1890 on the theory of systems in physical education, anthropometry, applied anatomy and other sciences, which were applied in class drills involving

67 exercises with weights, vaulting with bars and horses, tumbling and dancing. Sargent's systematic measurement of body proportions and research involving thousands of male and

69 female students that included physiological studies of respiratory capacity and grip strength, 
70

71

72

73

74

75

76

77

78

79

80

81

82

83

84

85

86

87

established that training approaches must be scientifically based. This same scientific rigor is evident in McKenzie's future cardiac studies [9]. Many of the machines used in gymnasiums throughout the United States such as rowing, pulley systems for specific muscle groups, and lifting were developed by Sargent. However, Sargent faced opposition to his scientific approaches to the study of physical conditioning by the conservative elements of academe. But, McKenzie predicted that Sargent's place in the history of physical education would be as "pioneer, thinker and scientist" [10].

It was during medical school at McGill University that McKenzie began to instruct students in gymnastics under the direction of James Naismith, Director of Athletics [11]. McKenzie's interest in exercise physiology developed during his years at the University, as is reflected in his appointment as Medical Director of Physical Training following graduation from medical school. Naismith would subsequently join another of Sargent's students, Luther H.

Gullick, MD, who was a pioneer in physical education and founded the first school at Springfield College. (Naismith and Gullick are credited with the invention of the game of basketball [12]). Following graduation from medical school, McKenzie became a close friend of and collaborator with Gullick and the two trained new directors of the YMCA in physical education. Gullick offered McKenzie a position at the YMCA in Springfield [13], but McKenzie chose not to join the YMCA for professional and personal reasons. McKenzie also taught anatomy at McGill and his appreciation of anatomy, kinesiology and sports was soon reflected in his art as a sculptor (Figure 1), which would earn him international recognition [14].

Although McKenzie had no specialized training in general surgery or orthopedic surgery following his internship in Montreal he restricted his practice to orthopedics and musculoskeletal diseases after he joined the faculty of the medical school at McGill. Graduates of Canadian and 
93 US medical Schools in the 1890s were licensed to practice medicine and surgery following an

94 internship of 1 year. If they restricted their practice to one field, such as orthopedic surgery, on a

95 full time or almost full time basis (personal communication Dr. David B. Levine), this validated

96 them as a specialist. McKenzie's earliest publications [15] deal with posture/exercises in the

97 prevention/treatment of scoliosis, and he is characterized later as an orthopedic surgeon with a

98 special interest in "orthopedic gymnastics" [16].

99

100

UNIVERSITY OF PENNSYLVANIA

101

Physiatrist Frank Krusen, considered the father of physical medicine [17] claims in his

102 accounts that McKenzie was the first professor of physical therapy in the nation [18], and

103 certainly he was one of the earliest to hold that appointment in a major US medical school - the

104 University of Pennsylvania, the oldest medical school in the nation. McKenzie's appointment as

105 Professor of Physical Therapy in 1907 [19] followed his appointment as Professor of Physical

106 Education in 1904. His early teaching included instruction in exercises that are applicable to

107 "curvature of the spine [and] locomotor ataxia", included in course work in physical education

108 for medical students [20] at the University. However, the Physical Laboratory was not

109 established in the hospital for the training in hydrotherapy and other therapies as part of medical

110 education until 1911-1912 [21]. Archival documents record that "Dr. Joseph Nylin, a trained

111 masseur...graduated from the University of Pennsylvania" joined the faculty as an associate to

112 McKenzie in 1912 [22]. Sophomore medical students were given a series of lectures twice a

113 week on exercises and massage for specific diseases; additional lectures were given to senior

114 students during medicine and surgery rotations. Demonstrations of hydrotherapy and other

115 physical modalities were added as the curriculum evolved [21]. 
Because of his dual role teaching physical education and physical therapy, McKenzie was

117 effective in introducing training programs in physical examination and exercise to improve the

118 health and correct educational deficiencies in the student population. In addition to these

119 innovative contributions to medical education, he made scientific observations and published his

120 findings in the medical literature during these early years at the University [23]. It is during this

121 period McKenzie began to write his classic textbook on exercise in health and disease. He states

122 his reasons for doing so in the following notation [19] shortly after his arrival at Penn in 1904:

123

124

125

"Living in Philadelphia, the home of the leading Medical publishers, and with a seat on a Medical faculty, each member of which had written a standard textbook on his subject, it was natural that the subject of writing would come up early." [19]

126 McKenzie is in fact approached by a leading publisher and finds that "at the time there are no 127 textbooks on the subject" [19]. Only one book had been published on exercise at that time, 128 Ferrand LaGrange's Physiology of Bodily Exercise [24]. But McKenzie held the view that "in the 129 realm of medicine...no attempt had been made to give a comprehensive view of the whole subject" [18]. McKenzie's textbook, Exercise in Education and Medicine, was first published in 1311909 [3] and is regarded by the founders of sports medicine and historians of physical education 132 as a classic [4,25]. It is praised as the "most comprehensive volume" that "brought physical 133 medicine, rehabilitation and athletic knowledge together" [26,27]. Berryman [4] places it with 134 Sargent's book in linking exercise with health and medicine. Part I is devoted to the 135 classification of exercise, massage, physiology of exercise, the German and Swedish schools of 136 exercise, and physical education in schools and for recreation. The second part of the book 137 focuses on the use of exercises in pathological conditions effecting posture, cardiovascular 138 disorders, neurological diseases such as locomotor ataxia, and treatments for obesity and 
139

140

141

142

143

144

145

146

147

148

149

150

151

152

153

154

155

156

157

158

159

160

161

musculoskeletal conditions. He is very precise in describing the accompanying symptoms and physical findings such as loss of balance with ataxia. He cites Silas Weir Mitchel, considered the father of neurology in USA, who explained a treatment protocol based on the exercises of Frankel, a German neurologist.

"The exercise treatment of ataxia...was used 40 years ago in America by Dr. Weir Mitchell...invented by Frankel, of Heiden [Germany]. ...rising from a chair the tabetic patient usually forgets to draw his feet backward. ,..He has ... to learn this simple coordination over again [3]."

With drawings, McKenzie maps out the progression of training exercises to restore balance during walking, indicating a favorable prognosis, and then he applies additional exercises for dressing and other activities of daily living. He cautions that the training of individuals should avoid excessive fatigue and advises monitoring pulse rate and respiratory parameters. This textbook includes the first comprehensive discussion of the "dosage" essential in the use of therapeutic exercise, and this discussion becomes the foundation for the prescription of exercise in $\mathrm{PM} \& \mathrm{R}[2]$.

McKenzie's 1913 publication on the influence of exercise on the heart [9] reflects his interest in cardiovascular physiology and cardiac rehabilitation, an interest that continues throughout his career. Dr. Joseph Wolffe, a cardiologist and one of the founders of the American College of Sports Medicine, praises McKenzie's early attention to cardiovascular exercise [25]. "Dr. McKenzie demonstrated, time and again, that response to exercise with few exceptions, proved to be a sound clinical test of the heart's ability to perform work and that functional heart murmurs, certain cardiac irregularities were untrustworthy guides in the evaluation of the integrity of the heart." 
162

163

164

165

166

167

168

169

170

171

172

173

174

175

176

177

178

179

180

181

182

183

184

\section{THE GREAT WAR}

Orthopedic surgeons at the beginning of the $20^{\text {th }}$ century, such as Robert Lovett [28], Robert Jones, Joel Goldthwait, Fred Albee, and Henry Kessler, had a comprehensive approach to the restoration of function that extended beyond their surgical skill. Several worked with physical therapy aides in civilian hospitals before the war, and the aides complemented the surgeon's efforts. These orthopedic surgeons also understood the importance of occupational therapy and vocational training. Kessler emphasized this appreciation in his book "The Knife is Not Enough" [29]. McKenzie was part of this tradition, but he brought a dimension of therapeutic exercise, which he extended into muscle re-education, functional training, gymnastics, sports and dancing. Opportunities to employ these unique aspects of therapeutic exercise were soon to unfold with events in Europe and the United States.

The advent of WW I provided an opportunity for physicians with interests in physical training and physical therapy to apply their skills to both enhance the fitness of inductees and restore function to the wounded and those with medical and post-surgical conditions.

McKenzie's patriotic fervor led him to take a leave of absence from the University for 18 months to join British forces in 1915 at the beginning of the War (Figure 2). He came under the command of Sir Robert Jones, "who founded the chain of orthopedic centers, to which reconstructive centers were attached" [5]. McKenzie indicates in a 1917 paper [30] on the treatment of neurological injuries that this approach attracted the attention of the Surgeon General of the United States.

"In the great orthopedic centers established throughout England by Lieutenant-Colonel Sir Robert Jones...[which] form[ed] the backbone of the treatment... the Surgeon General of the United States has already sent over a 
contingent of orthopedic surgeons to make themselves familiar with the subject and to establish centers to accommodate thirty-five thousand cases in France." McKenzie's first task was to assess the health status of soldiers determine unfit for service in the army.

"Arriving in England in 1915 he was distressed by the sight of many men who were unfit... Dr. McKenzie substituted health education, remedial physical training and recreation ... in the place of rest, inactivity and a life akin to hibernation. His experiments proved to be the most effective in hastening recovery of the sick... Gradually, it gained acceptance that properly supervised physical education revitalizes while prolonged rest devitalizes and cripples" [25].

McKenzie's treatment approaches for wounded soldiers combined traditional physical therapy modalities with his innovative concepts of precise therapeutic exercise programs, occupational therapy, and vocational retraining. His approach to the restoration of function of nerve injuries represents one of the first descriptions of the use of graded exercises with hydrotherapy and antigravity exercises. He reported [30] on a series of more than 500 cases (1917) in which he employed a system for grading of muscle strength and then applied muscle reeducation programs appropriate to the muscle strength. The muscle reeducation he describes as "progressive active movements...to bring back and strengthen voluntary power and later, gymnastic and vocational training". This approach is similar to Lovett's approach with polio cases [31] refined by Robert Bennett at Georgia Warm Springs in the 1940s [32].

McKenzie's appreciation of the benefits of occupational therapy and especially the use of adaptive equipment is unique for a military physician in 1916. His understanding of the 
207 distinction between occupational therapy and vocational training is clearly defined in his 208 textbook [5]:

"A distinction is frequently drawn between occupational therapy and vocational training. In the former, the movements are given as treatment, and the work done is a secondary consideration. The patient saws wood because the arm muscles can thus be contracted and relaxed a definite number of times. It is really a gymnastic exercise done with a saw. In vocational training the object is to make a good box by sawing the board in definite lengths, and the arm exercise is secondary, though essential."

In a letter [33] to the editor of the Journal of the American Medical Association (JAMA) in 1918,

217 he identifies "devices for men who have lost one or two arms" and this appears to be early 218 examples of adaptive feeding and recreational equipment for the upper extremity amputees 219 (Figure 3).

It is these scientific studies, case reports, and his success returning more than $70 \%$ of the war wounded under his care at Heaton Park to active service [34,35], which established his reputation in military circles as an expert in functional restoration of wounded soldiers.

223 McKenzie recognized the need for a physical therapy textbook to guide army physicians since 224 no text in English existed for the military at the time. He approached the development of his 225 handbook of physical therapy in the same fashion as his book on exercise in 1909, drawing from 226 exercises in the Swedish and German literature and improvising concepts of mechanotherapy 227 [34] that were influenced by Sargent and others. Granger [36] and Lovett [28] cite McKenzie’s 228 publications and expertise in mechanotherapy, which involved "machines" or apparatus for 
229

230

231

232

233

234

235

236

237

238

239

240

241

242

243

244

245

246

247

248

249

250

251 active and passive exercises to increase finger, wrist, shoulder and lower extremity range of motion and strength.

McKenzie's work on the rehabilitation of the "crippled soldier" was well known by

leaders in US medicine and surgery and is cited in W.W. Keen's classic surgical textbook [37].

Harry Mock, a pioneer industrial surgeon in the Surgeon General's Office, advised Frank

Billings, Head of Reconstruction and Rehabilitation in WW I, that McKenzie was "the only man

for the job" [38] to advise the US Army regarding physical therapy, and as a result Billings

invited McKenzie "to take charge of the department of physiotherapy to standardize the work

and to secure the proper personnel in physiotherapy that will enable us to do that work well" [39].

The subsequent success of rehabilitation hospitals in the US has been attributed to the pioneering efforts of US military physicians, such as Frank B. Granger, who set up the program of physical therapy in the US Army reconstruction hospitals [40]. The program that Granger implemented, however, was based on his visit to the British Army with Joel Goldthwait, head of

Orthopedic Surgery for the American Expeditionary Forces and their observations of the program in reconstruction hospitals of Great Britain that had been established under the leadership of McKenzie [27]. Granger's approach in the convalescent hospitals in France and the US, like McKenzie, stressed the team approach to rehabilitation. McKenzie's scientific publications before and during the war [30,34,35] and his Handbook on Physical Therapy: Reclaiming the Maimed [5], the official text and standard for British, Canadian and US armed forces, must have influenced all $[28,36]$ who shared it including professionals at the convalescent facility in France that physiatrist John Stanley Coulter headed [41]. 


\section{INFLUENCE ON GRANGER, MOCK, COULTER AND DEAVER: 1919-1930}

Developments in the United States immediately following the war reflected the

257 physicians in convalescent hospitals, pioneered by McKenzie and others, "formed the basis for modern Physical Medicine”[27]. For example, physiatric leaders Coulter, Granger, and Mock transitioned their efforts to raise the standards of research, education and practice in physical therapy, since many of the empirical claims were unsubstantiated, considered suspect and at times fraudulent by medical professionals. McKenzie's emphasis on the requirements of

262 scientific rigor is reflected in their work. Organizations were formed of physicians with special expertise in physical medicine and of physical therapy aides; both groups recognizing the need to 264 improve the standards of training (Table 1A).

267 connections to Granger and Mock during the war [42] are well documented, and within several 268 years he was elected the third president of the CPT. Granger founded and served as first 269 president of the Academy of Physical Therapy (APM), established in 1923 the same year as the 270 Congress of Physical Therapy. The APM was an organization which included former 271 electrotherapists, but many physical medicine physicians belonged to both organizations [43,44].

272 Both Granger and Coulter were strong advocates of improving the educational standards of 273 physical therapy aides following the war, and both were commended in historical accounts $274[45,46]$ of the American Physical Therapy Association (APTA). McKenzie's influence can be 
275 seen in the efforts of Granger and Coulter to strengthen the team approach to rehabilitation in

276 these organizations. These physician pioneers, like McKenzie [34], recognized that the physical

277 therapist aide's knowledge and skill was integral to raising the standards of physical therapy in

278 medical practice.

279 The creation of the AMA Council of Physical Therapy (AMACPT) in 1926 [47] was the

280 first official recognition of physical therapy physicians. The AMACPT was chaired by Mock,

281 who was well-versed in McKenzie and Granger's contributions. Most of the early reports of the

282 AMACPT dealt with safety and standardization of therapeutic modalities of heat, electricity, and

283 radium, with far less attention to therapeutic exercise, although exercise was listed as one of six

284 categories in the definition of modalities [47]. The following definition most likely reflects

285 McKenzie's influence on Mock:

286

Therapeutic Exercises.-Muscle training exercises, passive and active, mechanotherapy, occupational therapy, games.

288 While Mock was knowledgeable of physical therapy in his practice in Industrial Medicine, he 289 was not a full time practioner.

290 Frank Granger, however, who was appointed to the AMACPT in 1927 was the first full 291 time physical therapy physician [48]. Granger, while on the AMACPT, recognized McKenzie's 292 contribution to the invention of mechanical exercise equipment and the benefits of exercise in 293 competitive sports in addition to the need for better research to validate physiotherapy [36].

294 Following Granger's death in 1928, he was succeeded by Coulter to the AMACPT in 1931

295 ensuring continuity by full time practitioners of physical medicine. Although McKenzie was not 296 directly involved in these deliberations he continued to publish and present papers on sports and 297 to physical therapy societies [49,50] (Figure 4). 
Deaver, considered the grandfather of rehabilitation medicine [6], was likely exposed to the physical therapy course taught by McKenzie and Nylin when he was a sophomore and senior at the University of Pennsylvania before he entered the military. Deaver, a recent medical school graduate in 1917, familiar with the YMCA approach to physical training, also employed drills accompanied by music in his fitness training for soldiers [51]. Like McKenzie, Deaver applied exercise therapy and other physical therapies to rehabilitate the war wounded of WW I. McKenzie [52] and Deaver published back-to-back articles in the journal for directors of YMCA's on treatment of the war wounded [51,52]. Both trained masseurs and other staff to provide physical training, and both recognized that restoration of function was a team effort [53]. McKenzie and Deaver continued a relationship after the War during Springfield College reunions in Philadelphia in 1921 [54].

It is interesting to speculate on how these early experiences and Deaver's association with McKenzie may have influenced his choice of joining Coulter at Northwestern in 1930 [6], and his subsequent move to NYC, where his career in PM\&R unfolds, first with Coulter, then at the Institute for the Crippled and Disabled (ICD), and later with Rusk at New York University (NYU).

This approach of restoring the war wounded to optimal functioning with a team effort, first reported by McKenzie and Deaver in WW I, was expressed again in Deaver's relationship with Howard Rusk. Early in WWII, Rusk approached Deaver, when he met him at the ICD and asked his advice regarding the establishment of rehabilitation centers for the Air Force. "Do you think you could set up such a program?" Deaver replied that they had already offered such a program to the Army and VA, but was told it was not needed. Rusk replied "We need it in the Air Force" and Deaver replied "We'll be glad to do it for you" [55, p 3-29). 
The year 1930 is significant for the field of PM\&R, because a number of important

322 events occurred in the lives of these early pioneers. Following Granger's death, Coulter

323 succeeded him on the AMACPT, McKenzie retired, and Deaver joined Coulter at Northwestern

324 University. Krusen began publishing on physical therapy, which led to his recruitment to the

325 Mayo Clinic and his departure from Temple University in 1935 [17] (Table 1B).

326

327

328

329

330

\section{INFLUENCE ON PHYSICAL MEDICINE 1931-1938 AND BEYOND}

In 1934, McKenzie became active in the Academy of Physical Medicine (APM), originally founded in 1923 by Granger as the Academy of Physical Therapy [44]. McKenzie chaired a symposium at the annual APM meeting in 1936, which featured the first Director of the London Hospital Department of Physical Medicine, Sir Robert Stanton Woods, two national experts from Columbia University and the Sargent School in physical education, and a presentation on exercise physiology from the Harvard Fatigue Laboratory (HFL). This was an example of efforts to update physical medicine in regard to exercise physiology and physical education. Inviting participation by a member of the HFL illustrates his visionary leadership concerning the importance of the physiology of exercise as a necessary component of future research in PM\&R. His judgment in 1936 is validated, since The Harvard Fatigue Laboratory, when viewed 6 decades later, is recognized as having attracted some of the most important leaders in this field [56]. Robert Darling [57] former chair of PM\&R at Columbia and Edward Gordon of Chicago and Jefferson Medical College are products of this research environment in the 1940s.

Although, McKenzie like Deaver [58] did not play a major role in organized PM\&R, he was elected president of the APM in 1938. This is a critical year in the development of Physiatry 
344 as a specialty. McKenzie is aware of the achievements of the AMA Council on Physical Therapy

345 and recognized this in his presidential letter to the members of the ACP in 1938 [43]. of a specialty board had arrived [42]. Krusen and the leadership of the CPT had already approached the APM, while McKenzie was an officer, to consolidate with the Congress of physical therapy. This was a strategy in preparation for the formation of the Society of Physical Therapy Physicians (SPTP), whose primary purpose was to work for specialty status [58]. It is unclear what McKenzie's position was on this movement since he died prior to the meeting, but events unfold and leadership for these efforts are identified in the next two years, and the outcome was momentous for PM\&R. In 1938 Krusen is elected president of CPT and Coulter becomes the first president of the newly formed Society of Physical Therapy Physicians. This organization became the American Academy of Physical Medicine (AAPM\&R) in 1954. Although Krusen was named chair of the Research Committee of the APM by McKenzie, together with Mock and Albee in 1938, he continued his efforts toward consolidation and through his leadership in the Congress for the future recognition of the Board of PMR. The members of the APM became absorbed into the SPTP and the Congress over the next few years; in Coulter's history of physical medicine in 1946 [48] he names only two organization representing physical medicine, the Congress and the Society of Physical Medicine. 
366 Many of these pioneers who were former members of the APM and of the CPT (later the ACRM

367 (Table 1B) and played key roles on behalf of the specialty during and/or following the war, will

368 be recognized by the ACRM's Gold Key Award [59]. These leaders included Goldthwaite

369 (1935), Mock (1937), Coulter (1943), Krusen (1944), Deaver and Kessler 1953.

370

McKenzie's legacy at the University of Pennsylvania is well documented [60]. Dr.

371 Joseph Nylin, who succeeded him in 1931 presented a paper at APM in 1938 together with

372 Krusen and Walter Zeiter [61]. Nylin is listed as one of the charter members of the SPTP the

373 following year [58], and this links McKenzie's legacy at Penn with the future AAPM\&R.

374 Following Nylin's death in 1945, George Morris Piersol, an orthopedic surgeon who was well

375 known to McKenzie, succeeds him. Piersol gained national recognition in PM\&R and received

376 the Gold Key Award of the Congress in 1954 joining many of the earlier pioneers. Piersol

377 groomed William Erdman as his successor that same year and Erdman became a major physiatric

378 leader during the next 3 decades.

379

CONCLUSION

McKenzie's vision of physical medicine and rehabilitation (PM\&R) through the prism of

382 physical education reveals the major taproot that fed the early growth of Physiatry. As a scientist

383 with an appreciation of exercise physiology, and as a physician with an understanding of the

384 pathophysiology of trauma and disease, he was able to apply accurate anatomic, physiologic, and

385 kinesiologic measurements, develop specific training programs and design recreational and

386 vocational activities to restore maximum function without injury or other negative outcomes for

387 patients with many different conditions. He was perhaps the first physician scientist to articulate

388 the concepts we embrace today for retraining individuals with sports injuries and neurotrauma. 
389 His national stature as a pioneer in sports medicine, an artist, a physical educator and PM\&R 390 physician $[25,27,62]$ is well-deserved. His legacy to the practioners of PMR such as Granger, 391 Coulter, and Deaver extends to partners in physical and occupational therapy, kinesiology and 392 biomechanics, because he understood these basic concepts and appreciated the requirement of a 393 team effort to achieve the best results.

394

395 Acknowledgments: The authors wish to acknowledge the assistance of Nancy R. Miller, 396 Archivist University of Pennsylvania Archives and The William J. Erdman, II, Professor and 397 Chair of Physical Medicine and Rehabilitation, Dr. Timothy R. Dillingham of the Perelman 398 School of Medicine, University of Pennsylvania.

399

400

401

402

403

404

405

406

407

408

409

410

411 
414 References

415 1. Garber CE, Blissmer B, Deschenes MR, et al. American College of Sports Medicine position stand. Quantity and quality of exercise for developing and maintaining cardiorespiratory, musculoskeletal, and neuromotor fitness in apparently healthy adults: guidance for prescribing exercise. Medicine and Science in Sports and Exercise 2011;43:1334-59.

420

421 2. Exercise prescription and basic principles of therapeutic exercise. Chicago, Ill.: American Academy of Physical Medicine and Rehabilitation; 2014. Available at: http://now.aapmr.org/rehab-essentials/special-assessment-mgmt-strategy/Pages/Exerciseprescription-and-basic-principles-of-therapeutic-exercise.aspx Accessed June 21, 2014.

425

3. McKenzie RT. Exercise in Education and Medicine. Philadelphia. London: W B Saunders company; 1909, 10. Available at: https://archive.org/details/exerciseineducat01mcke Accessed June 30, 2014. 2010;9:195-201. 
5. McKenzie RT. Reclaiming the Maimed: A Handbook of Physical Therapy. New York: Macmillian; 1918, 106. Available at : https://archive.org/details/reclaimingmaimed00mcke Accessed June 30, 2014.

6. Flanagan SR, Diller L. Dr. George Deaver: the grandfather of rehabilitation medicine. PM \& R: the journal of injury, function, and rehabilitation 2013;5:355-9.

7. McKenzie RT. Autobiography, Outline (McGill). Collection UPT 50 McK37, box 7, folder 48, R. Tait McKenzie Papers, University of Pennsylvania Archives, Philadelphia, PA Available at: http://www.archives.upenn.edu/faids/upt/upt50/mckenzie_rt.html Accessed June 23, 2014.

8. McKenzie RT. Autobiography, Outline (Sargent). Collection UPT 50 McK37, box 7, folder 48, R. Tait McKenzie Papers, University of Pennsylvania Archives, Philadelphia, PA Available at: http://www.archives.upenn.edu/faids/upt/upt50/mckenzie_rt.html Accessed June 23, 2014.

9. McKenzie RT. The influence of exercise on the heart. American Journal of Medical Sciences 1913;145:69-74.

10. Dudley Allen Sargent: An Autobiography: Lea \& Febiger; 1927, Introduction by R. Tait McKenzie, xvi. 
11. McKenzie RT. Autobiography, Outline (Naismith). Collection UPT 50 McK37, box 7, folder 48, R. Tait McKenzie Papers, University of Pennsylvania Archives, Philadelphia, PA Available at: http://www.archives.upenn.edu/faids/upt/upt50/mckenzie_rt.html Accessed June 23, 2014.

12. Naismith JG, L. Basketball: A book written by Dr. James Naismith and Dr. Luther Gullick, 1894. Springfield, Mass.: American Sports Publishing Company; 1894, 1-35. Available at: http://cdm16122.contentdm.oclc.org/cdm/ref/collection/p15370coll2/id/344 Accessed June 30, 2014.

13. McKenzie RT. Autobiography, Chapter 3. (Gullick). Collection UPT 50 McK37, box 7, folder 58, R. Tait McKenzie Papers, University of Pennsylvania Archives, Philadelphia, PA Available at: http://www.archives.upenn.edu/faids/upt/upt50/mckenzie_rt.html Accessed June 23, 2014.

14. Kozar AJ. Sport Sculpture of R. Tait McKenzie. 2nd ed. Champaign, Il.: Human Kinetics Books; 1992, 1-136.

15. McKenzie RT. The Influence of School Life on Curvature of the Spine. American Physical Education Review 1898;3:274-80.

16. McKenzie R.T. Letter C. S. W. Packard to R. Tait McKenzie May 19, 1904. Collection UPT 50 McK37, box 5, folder 36, R. Tait McKenzie Papers, University of Pennsylvania 
Archives, Philadelphia, PA Available at:

http://www.archives.upenn.edu/faids/upt/upt50/mckenzie_rt.html Accessed June 23, 2014.

17. Kinney CL, DePompolo R. "Rehabilitation ... a key word in medicine": the legacy of Dr. Frank H. Krusen. PM \& R: the journal of injury, function, and rehabilitation 2013;5:1638.

18. Krusen FH. History And Development Of Physical Medicine. Clinics 1946;4:1343-55.

19. McKenzie RT. Autobiography, Chapter 2 (Phila). Collection UPT 50 McK37, box 7, folder 54, R. Tait McKenzie Papers, University of Pennsylvania Archives, Philadelphia, PA Available at: http://www.archives.upenn.edu/faids/upt/upt50/mckenzie_rt.html Accessed June 23, 2014.

20. University Catalogue 1907/1908, Department of Physical Education p 526-27. Archival Collections 1820-1930 University of Pennsylvania Archives. Available at: http://www.archives.upenn.edu/faids/upa/upa3/upa3index.html Accessed June 24, 2014.

21. University Catalogue, 1911/1912, Department of Physical Education p 515. Archival Collections 1820-1930 University of Pennsylvania Archives. Available at: http://www.archives.upenn.edu/faids/upa/upa3/upa3index.html Accessed June 24, 2014. 
504

505

506

507

508

509

510

511

512

513

514

515

516

517

518

519

520

521

522

523

524

22. Josef B. Nylin. University of Pennsylvania Recorder's Office. University of Pennsylvania Archives, Philadelphia, PA.

23. McKenzie RT. The Regulation of Physical Instruction in Schools and Colleges from the Standpoint of Hygiene. Science 1909;29:481-4.

24. Lagrange F. Physiology of Bodily Exercise. New York: D. Appelton and Company; $1890,1-395$.

25. Wolffe JB. A Man Unique In History. Ottawa, Ontario Canada: Physical and Health Education 1963.

26. Wrynn AM. The Athlete in the Making: The Scientific Study of American Athletic Performance, 1920-1932. Sport in History 2010;30:121-37.

27. Mason F. Sculpting soldiers and Reclaiming the Maimed: R. Tait McKenzie's work in the First World War period. Can Bull Med Hist 2010;27:363-83.

28. Lovett RW. The problem of the reconstruction and re-education of the disabled soldier. Surg, Gynec \& Obst 1918;27.

29. Kessler HH. The Knife Is Not Enough. New York: W. W. Norton and Company; 1968, 1295. 
525

526

527

528

529

530

531

532

533

534

535

536

537

538

539

540

541

542

543

544

545

546

547

30. McKenzie RT. The treatment of nerve, muscle, and joint injuries in soldiers by physical means. Canadian Medical Association journal 1917;7:1057-68.

31. Lovett RW. The Treatment of Infantile Paralysis. Philadelphia: P. Blakiston's son \&co.; $1916,1-175$.

32. Ditunno JF, Jr., Verville RE. Dr. Robert L. Bennett: pioneer and definer of modern physiatry. PM \& R: the journal of injury, function, and rehabilitation 2013;5:83-9.

33. McKenzie RT. Devices for Disabled Men JAMA 1918;71:1683.

34. McKenzie RT. The Treatment of Convalescent Soldiers by Physical Means. British medical journal 1916;2:215-8.

35. McKenzie RT. The Treatment of Convalescent Soldiers by Physical Means (with Appendices: Guide to Medical Examinations-Remedial Exercises-Tables of ExercisesObservations on Heart Conditions by H. J. Seeuwan, M.D.). Proceedings of the Royal Society of Medicine 1916;9:31-70.

36. Granger FB. The Use and Abuse of Physical Therapeutics JAMA 1927;89:1194-98.

37. Keen WW. The Treatment of War Wounds. Philadelphia: W. B. Saunders Co.; 1918, 23. 
38. McKenzie RT. Letter Harry E. Mock to R. Tait McKenzie October 24, 1918. Collection UPT 50 McK37, box 5, folder 36, R. Tait McKenzie Papers, University of Pennsylvania

551

552

553

554

555

556

557

558

559

560

561

562

563

564

565

566

567

568

569

570
Archives, Philadelphia, PA Available at:

http://www.archives.upenn.edu/faids/upt/upt50/mckenzie_rt.html Accessed June 23, 2014.

39. Billings F. Reconstruction and Rehabilitation of Disabled Soldiers: Chairman's Address; The National Program On Reconstruction and Rehabilitation of Disabled Soldiers. JAMA 1918;70:1924-31.

40. Dillingham TR. Physiatry, physical medicine, and rehabilitation: historical development and military roles. Physical medicine and rehabilitation clinics of North America 2002;13:1-16, v.

41. Hansson KG. Doctor John Stanley Coulter 1885-1949. Archives of Physical Medicine and Rehabilitation 1951;32:629-31.

42. Verville R. War, Politics, and Philanthropy: The History of Rehabilitation Medicine. Lanham, Maryland: University Press of America; 2009,34-39.

43. McKenzie RT. Academy of Physical Medicine, 1936-1938. Collection UPT 50 McK37, box 4, folder 43, R. Tait McKenzie Papers, University of Pennsylvania Archives, 
577

578

579

580

Philadelphia, PA Available at:

http://www.archives.upenn.edu/faids/upt/upt50/mckenzie_rt.html Accessed June 23, 2014.

44. McFee WD. R. Tait McKenzie, President of the American Academy of Physical Medicine, 1937-1938. J Health \& Phys Ed 1944;15:76-90.

45. Vogel EE. Physical Therapists Before World War II (1917-40). In: Anderson E, ed. Army Medical Specialist Corps. Washington, D.C.: U. S. Army Medical Department Office of Medical History; 1968. Available at: http://history.amedd.army.mil/corps/medical_spec/chapterIII.html Acessed June 30, 2014.

46. Hazenhyer IM. A History of the American Physiotherapy Association. The Physiotherapy Review 1946;26:3-14.

47. Report of Committee on the Present Status of Physical Therapy. JAMA 1926;87:1302.

48. Coulter JS. History and development of physical medicine. Archives of Physical Medicine and Rehabilitation 1947;28:600-2.

49. McKenzie RT. The Place of Manipulation and Corrective Gymnastics in Treatment. California state journal of medicine 1923;21:480-2. 
50. McKenzie RT. An Address on the Functions and Limits of Sport in Education. Canadian Medical Association journal 1926;16:630-2.

597

598

51. Deaver GG. Physical training of the wounded in Egypt. Physical Training 1919;XVI:5.

599

600

52. McKenzie RT. The Place of the Physical Director in the Rehabilitation of the Wounded.

601 Physical Training 1919;XVI:4.

602

603

53. Wyrnn AM. "Under the Showers": An Analysis of the Historical Connections between

604 American Athletic Training and Physical Education. Journal of Sport History

605 $2007 ; 34: 37-52$.

606

607

54. McKenzie RT. YMCA, 1921-1922. Collection UPT 50 McK37, box 5, folder 32, R. Tait

608 McKenzie Papers, University of Pennsylvania Archives, Philadelphia, PA Available at:

609 http://www.archives.upenn.edu/faids/upt/upt50/mckenzie_rt.html Accessed June 23,

610 2014.

611

612

613

55. Rusk HA. A World to Care For: The Autobiography of Howard A. Rusk. New York, NY: Random House; 1972, 63.

614

615

56. Tipton CM. Contemporary exercise physiology: fifty years after the closure of Harvard 616 Fatigue Laboratory. Exercise and sport sciences reviews 1998;26:315-39. 
57. Darling RC, Eichna LW, et al. Physical fitness; report of the subcommittee of the Baruch Committee on physical medicine. JAMA 1948;136:764-7.

620

58. Kottke FJ, Knapp ME. The development of Physiatry before 1950. Archives of physical medicine and rehabilitation 1988;69 Spec No:4-14.

622

623

59. Gold Key Award. Chicago, Ill.: American Congress of Rehabilitation Medicine; 2014.

624 Available at: https://www.acrm.org/about/awards/gold-key-award/ Accessed June 21,

625 2014.

626

627

60. Fishman AP. The History of the Department of Rehabilitation Medicine. 1997. Available 628 at: http://www.pennmedicine.org/physical-medicine-rehabilitation/documents/historicalperspective.pdf Accessed June 30, 2014.

630

61. Zeiter WJ. The history of the American Congress of Physical Medicine and Rehabilitation. Archives of physical medicine and rehabilitation 1954;35:683-8. 89. 
Tables

644

645

646

647

648

649

650

651

652

653

654

655

656

657

658

659

660

661

662

663

664

665

666

667

668

669

670

671
Table 1 A. Timelines for organizations and abbreviations for Physical Therapy (Physical Medicine and Rehabilitation) organizations.

\begin{tabular}{|c|c|c|}
\hline Name & abbreviation & Membership \\
\hline $\begin{array}{l}\text { American Society of Physical Therapy Physicians } 1938 \\
\text { American Society of Physical Medicine } 1944 \\
\text { American Society of Physical Medicine and Rehabilitation } 1951 \\
\text { American Academy of Physical Medicine and Rehabilitation } 1955\end{array}$ & $\begin{array}{l}\text { ASPTP or SPTP } \\
\text { ASPM } \\
\text { ASPM\&R } \\
\text { AAPM\&R }\end{array}$ & $\begin{array}{l}\text { Physiatrists } \\
\text { requiring Board } \\
\text { certification }\end{array}$ \\
\hline $\begin{array}{l}\text { American College of Radiology and Physiotherapy } 1923 \\
\text { American Congress of Physical Therapy } 1925 \\
\text { American Congress of Physical Medicine } 1944 \\
\text { American Congress of Physical Medicine and Rehabilitation } 1952 \\
\text { American Congress of Rehabilitation Medicine }\end{array}$ & $\begin{array}{l}\text { ACRP } \\
\text { ACPT } \\
\text { ACPM } \\
\text { ACPM\&R } \\
\text { ACRM }\end{array}$ & $\begin{array}{l}\text { Physiatrists and } \\
\text { related medical } \\
\text { professionals }\end{array}$ \\
\hline $\begin{array}{l}\text { American Academy of Physical Therapy 1923 } \\
\text { American Academy of Physical Medicine 1933-1944 }\end{array}$ & $\begin{array}{l}\text { AAPT or APT } \\
\text { AAPM }\end{array}$ & $\begin{array}{l}\text { Physicians with } \\
\text { interest/skill in } \\
\text { Physical Medicine }\end{array}$ \\
\hline
\end{tabular}


672

673

674

675

676

677

678

Table 1 B. Timelines Pioneers in Physical Medicine and Rehabilitation

\begin{tabular}{|c|c|c|c|c|}
\hline Leaders & Years & Title & Organization & Events \\
\hline McKenzie & $\begin{array}{l}1904-7 \\
\text { to } \\
1930 \\
\end{array}$ & Professor & $\begin{array}{l}\text { University of } \\
\text { Pennsylvania School of } \\
\text { Medicine }\end{array}$ & $\begin{array}{l}1^{\text {st }} \text { Professor of Physical Education \& } \\
\text { Physical Therapy in US. "Interest in } \\
\text { orthopedic gymnastics" (Packard) }\end{array}$ \\
\hline McKenzie & $\begin{array}{l}1915- \\
19\end{array}$ & Major & $\begin{array}{l}\text { British Armed Forces \& } \\
\text { consultant to Canadian \& } \\
\text { US Armed forces }\end{array}$ & $\begin{array}{l}\text { WW I } 1^{\text {st }} \text { Handbook Physical Therapy } \\
\text { in US. }\end{array}$ \\
\hline Granger & $\begin{array}{l}1906- \\
1917\end{array}$ & Instructor & $\begin{array}{l}\text { Tuft \& Harvard Medical } \\
\text { Schools }\end{array}$ & Major interest electrotherapeutics \\
\hline Granger & $\begin{array}{l}1917- \\
19\end{array}$ & Colonel & US Army & $\begin{array}{l}\text { WW I Head Physical Therapy US } \\
\text { Army }\end{array}$ \\
\hline Granger & $\begin{array}{l}1919- \\
1929\end{array}$ & $\begin{array}{l}\text { Assistant } \\
\text { Professor }\end{array}$ & Tufts Medical School & $\begin{array}{l}\text { APT } 1923 \text { Founder } \\
\text { AMA Council Physical Therapy } 1^{\text {st }} \\
\text { Physical Therapist MD } 1926\end{array}$ \\
\hline Coulter & $\begin{array}{l}1911- \\
1920\end{array}$ & $\begin{array}{l}\text { Lieutenant } \\
\text { Colonel }\end{array}$ & US Army (1911-20) & $\begin{array}{l}\text { WW I Head } 1^{\text {st }} \text { US Convalescent } \\
\text { Rehabilitation Hospital in France } 1918\end{array}$ \\
\hline Coulter & $\begin{array}{l}1926- \\
1949 \\
\end{array}$ & $\begin{array}{l}\text { Professor \& } \\
\text { Chair }\end{array}$ & Northwestern University. & $\begin{array}{l}\text { President Congress } 1926 \\
\text { AMA Council PT } 2^{\text {nd }} \text { MD } 1931\end{array}$ \\
\hline Krusen & $\begin{array}{l}1926- \\
1935\end{array}$ & $\begin{array}{l}\text { Associate } \\
\text { Dean }\end{array}$ & Temple Medical School & $\begin{array}{l}\text { Physical Medicine } \\
1^{\text {st }} \text { Physical Medicine Department US }\end{array}$ \\
\hline Krusen & $\begin{array}{l}1935- \\
1965\end{array}$ & $\begin{array}{l}\text { Professor \& } \\
\text { Chair }\end{array}$ & $\begin{array}{l}\text { Mayo Clinic; University } \\
\text { of Minnesota Medical } \\
\text { School. }\end{array}$ & $\begin{array}{l}\text { President APM } 1936 \\
1938 \text { SPTP with Coulter } \\
1947 \text { Chair ABPMR } \\
\end{array}$ \\
\hline Deaver & $\begin{array}{l}1931- \\
1932\end{array}$ & Instruct & $\begin{array}{l}\text { Northwestern University } \\
\text { School of Medicine }\end{array}$ & Joins Coulter \\
\hline Deaver & $\begin{array}{l}1932- \\
1937-\end{array}$ & $\begin{array}{l}\text { Medical } \\
\text { Advisor }\end{array}$ & NYU School PT & $\begin{array}{l}\text { Directed training in therapeutic } \\
\text { exercises, surgery and orthopedic } \\
\text { surgery }\end{array}$ \\
\hline Deaver & $\begin{array}{l}1938- \\
1946\end{array}$ & Director & $\begin{array}{l}\text { Institute Crippled \& } \\
\text { Disabled }\end{array}$ & $\begin{array}{l}\text { Publishes } 1^{\text {st }} \text { Text Activities of Daily } \\
\text { Living (ADL) }\end{array}$ \\
\hline Deaver & $\begin{array}{l}1947- \\
1969 \\
\end{array}$ & Professor & Institute PM\&R & \\
\hline Rusk & $1940 \mathrm{~s}$ & Major & US Army & WW II Rehabilitation Hospitals \\
\hline Rusk & $\begin{array}{l}1945- \\
1980 \\
\end{array}$ & $\begin{array}{l}\text { Professor \& } \\
\text { Chair }\end{array}$ & New York University & Founded Institute PM\&R \\
\hline
\end{tabular}


697 698 699

700

701

702 Figure 3 - Illustration of mechanotherapy for finger injury [34]. Machine for exercising the 703 fingers. First position. Finger extended. Movement. Flexion at the meta-carpophalangeal joints. 704 Movement represented by dotted lines. (Weights In ounces).

705

706

707 708

\section{Figure Legends}

Figure 1 - Flying Sphere. McKenzie was a world renowned sculpture of athletes [14,25,27] and the Flying Sphere was modeled from a study in motion by Muybridge. Courtesy of the University of Pennsylvania Archives.

Figure 2 - Major McKenzie at Heaton Park Depot, England 1915. Courtesy of University of Pennsylvania Archives.

Figure 4 - R. Tait McKenzie. Professor of Physical Education and Professor of Physical Therapy at University of Pennsylvania. Courtesy of the University of Pennsylvania Archives 
Click here to download high resolution image

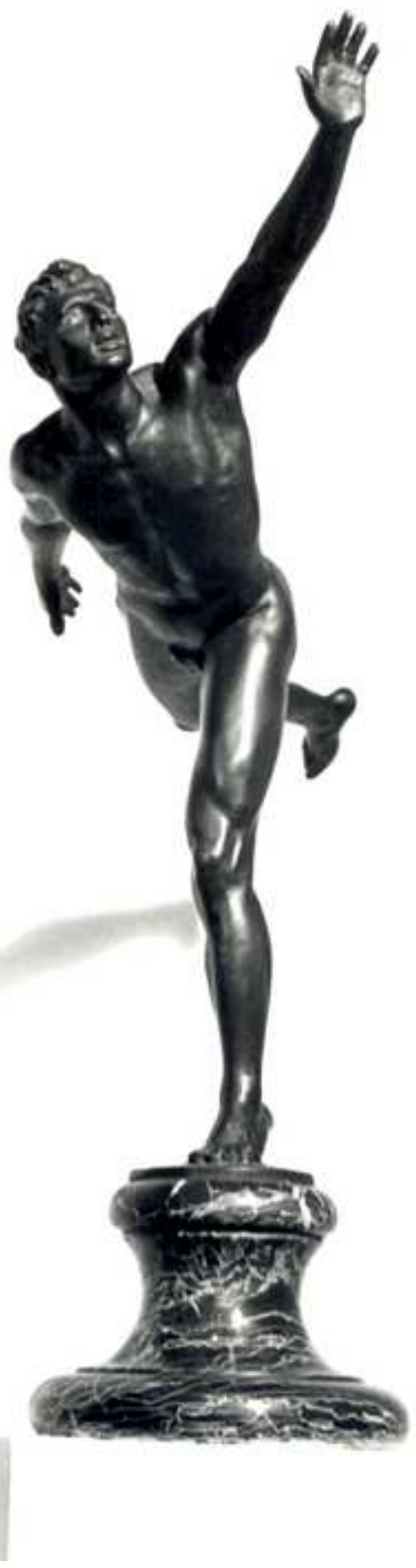




\section{Figure 2}

Click here to download high resolution image

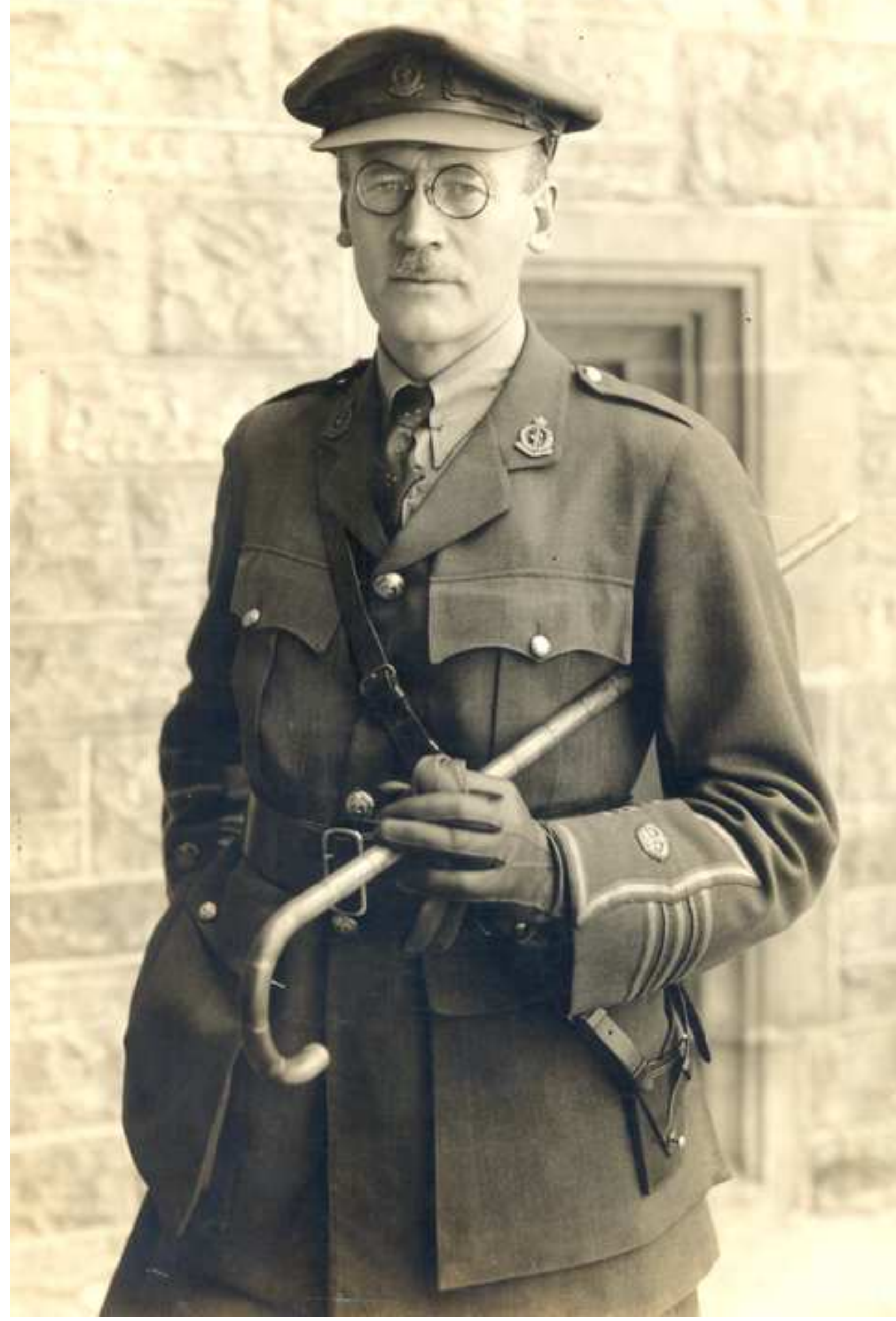


Figure 4
Click her

Click here to download high resolution image

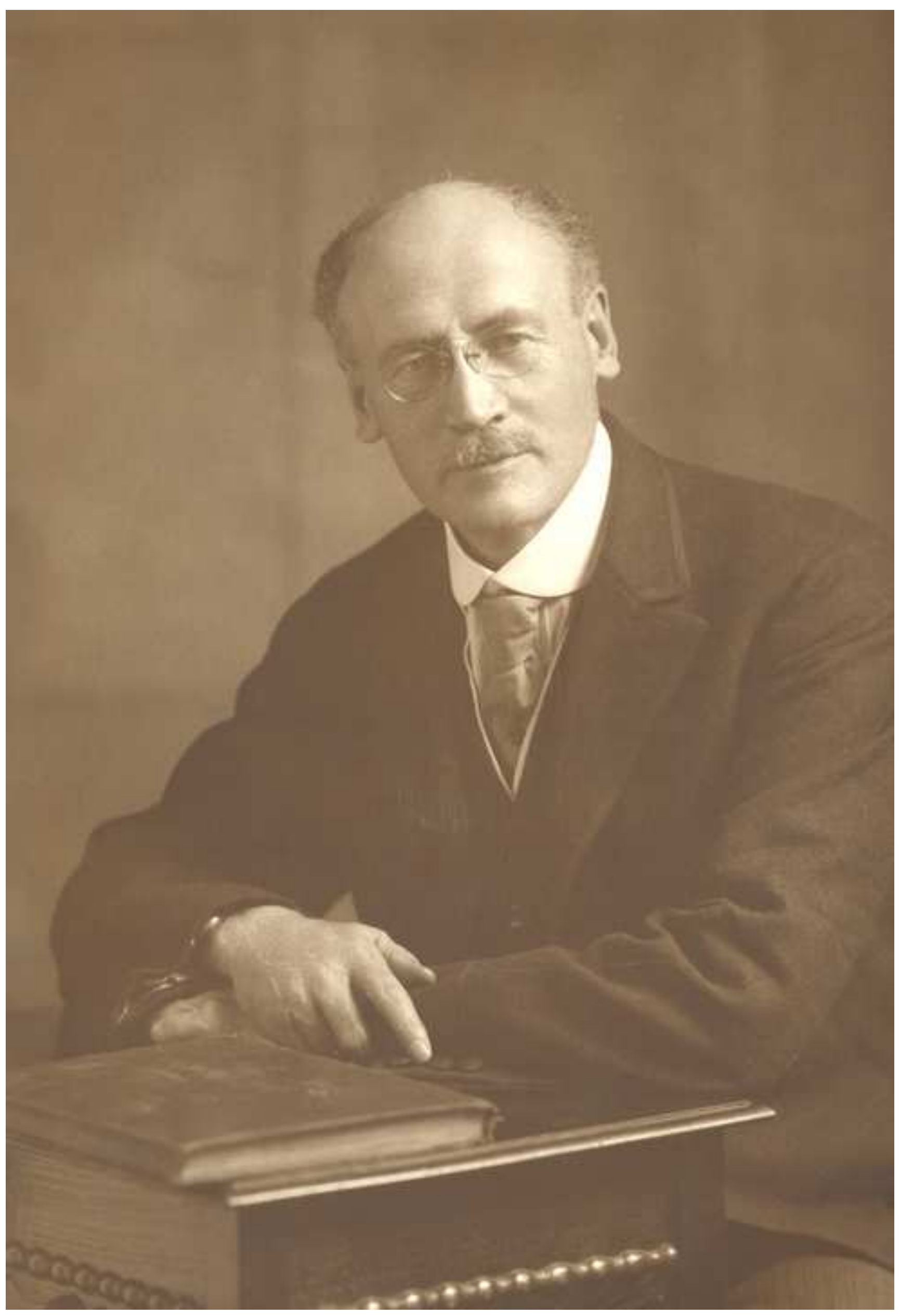


Conditions for Submission Form

Click here to download Conditions for Submission Form: Condition for submission form - Ditunno.jpg 
Conditions for Submission Form

Click here to download Conditions for Submission Form: Signed PM R Conditions for Submission Form Verville.pdf 